Variations sur la lettre, le mètre et la mesure :

Shakespeare

\title{
Ars combinatoria: Marlowe and the art of framing
}

\section{Roy Eriksen}

\section{(2) OpenEdition \\ 1 Journals}

Electronic version

URL: http://journals.openedition.org/shakespeare/977

DOI: $10.4000 /$ shakespeare.977

ISSN: 2271-6424

Publisher

Société Française Shakespeare

\section{Printed version}

Date of publication: 1 November 1996

Number of pages: 111-126

\section{Electronic reference}

Roy Eriksen, «Ars combinatoria: Marlowe and the art of framing », Actes des congrès de la Société française Shakespeare [Online], 14 | 1996, Online since 01 January 2007, connection on 23 April 2019. URL : http://journals.openedition.org/shakespeare/977 ; DOI : 10.4000/shakespeare.977 


\section{Variations sur la lettre,}

le mètre et la mesure

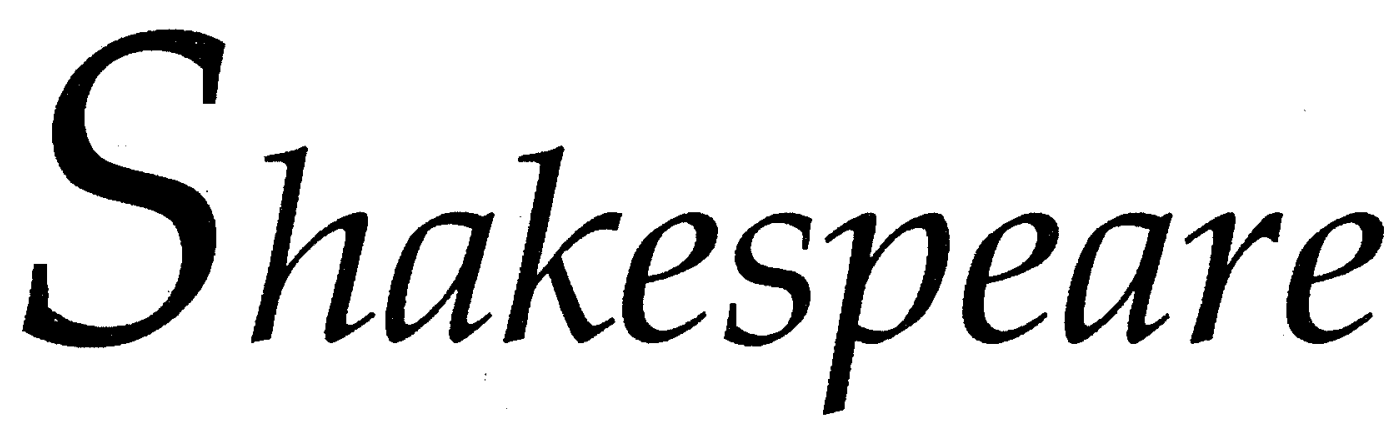

textes présentés par Dominique Goy-Blanquet

Directeur de la publication : Richard Marienstras 


\section{Ars combinatoria Marlowe and the art of framing}

What are the aesthetic assumptions behind Marlowe's art of framing ? The pioneering Elizabethan dramatist has not left us any treatise in which he presented his definition of poetry in English, but if we read the clues given by his extant work we may get a fairly good idea of his ideals. A sonnet in 1 Tamburlaine thus alludes to what I define as a poetics of verbal contrivance and artful combination :

What is beauty, saith my sufferings then?

If all the pens that ever poets held

Had fed the feeling of their masters' thoughts,

And every sweetness that inspir'd their hearts,

Their minds, and muses on admired themes.

If all the heavenly quintessence they still

From their immortal flowers of poesy,

Wherein as in a mirror we perceive

The highest reaches of a human wit,

If all had made one poem's period,

And all combin'd in beauty's worthiness,

Yet should there hover in their restless heads

One thought, one grace, one wonder at the least,

Which into words no virtue can digest.

(V.1.160-73; my emphasis)

Terms like "flowers of poesy", "grace", and "wonder", suggest a preference for the elegant and striking style referred to as Mannerism, while allusions to infinite quest conform with more traditional views of Marlowe as an iconoclast and "overreacher". How can we explain these contrary signals and how does Marlowe combine the "flowers of poesy" to form "one poem's period" ?

Although in many ways useful when it comes to elucidating certain aspects of Marlowe's extraordinary success in the late 1580s, the latter Romantic view of the author can only explain part of Marlowe's dramatic art and its verbal and scenic power. For when Tamburlaine the Great thunders onto the stage, humanist rhetoric finds a new outlet into the Elizabethan social space. ${ }^{1}$ Energies are released which long had been kept in check or firmly regulated in modes of unoriginal writing where authors best fulfilled their task in society by repeating what had already been written, either by producing translations of the classics or "emptying one compendium of exempla into another, varying the text as little as possible."2 The dramatic 


\section{ARS COMBINATORIA}

medium with its bodying forth of notions in prosopopeias, or speaking pictures, seems to have altered this situation almost over night, but the novel movement is clearly visible in a number of works in various fields. ${ }^{3}$ Yet on stage delivery is the final and outward sign in the compositional processes producing dramatic speech. Delivery or actio only arrives (after memoria) in fifth position in the five-fold process of composition as outlined in rhetorical doctrine $:^{4}$ first, in inventio, comes the devising of the poet's "plat", then in dispositio enters the formal fashioning of the poem in the distribution of materials, and thirdly in elocutio the poet clothes the invention with words, observing the appropriate "metrical proportions".

In the case of Marlowe these proportions involve creating the firm, muscular rhythms of the mighty line. The secret power of his dramatic poetry is located primarily in the two first stages of this process : his technique is equally "edifying" in a humanist sense of the word as it is "overreaching". Here I naturally see the aspect of overreaching as the mannerist element in the equation. In brief, it is in his humanist method of plotting or working from a rhetorical "plat" or "fore-conceit" that the mighty line acquires that additional force which makes it superior to earlier attempts at writing blank verse. His renowned ability to strike an audience dead is to be sought within the context of the invention of well-constructed or "framed" speech. ${ }^{5}$ To argue this point I will return to a speech in Tamburlaine, Part One, II.7.17-26 and its grand reference to "the wondrous architecture of the world". The speech and the aesthetic ideal it embodies must be related to the humanist rhetorical context of what Sidney referred to as the Greeks' architectonike, or "the highest or [...] ending end of all earthly learning being virtuous action." 6 The phrase would then not only refer to the world as a palace with a concave superficies, ${ }^{7}$ but to "the theoria of the world" (2 Tamburlaine, IV.3.85). Full of "wondrous miracles", this theoria is identical with "the wondrous architecture of the world" which is the end of Tamburlaine's quest for "knowledge infinite" through the application of his virtue in acts of speech and in physical conquest alike. This speech is a site where Marlowe meditates on his art and its ultimate goals, using the terminology and the techniques of humanism rhetoric and poetics. In this respect the speech can be said to equal the prologues in Tamburlaine or Doctor Faustus in importance, or indeed Marlowe's Latin epistle to Mary Sidney about the laurigera stirpe of his lost sonnets. ${ }^{8}$

In recent years new historicist and cultural materialist studies of Renaissance drama texts have highlighted the mutually shaping power of drama and ideology. In a fine study of Nashe Lorna Hutson focuses on what she terms "the profitable discourse" of the Elizabethans, drawing attention to the parallels between social and artistic plotting. However, the insistence on edification in a moral or economic sense and the need to work from a plat or plot can be and was pursued on other levels than the purely ideological, and the practice of working from an abstract plan may yield important information about how literary works were plotted in a spatial sense so as to become "profitable". For how exactly is power represented and conveyed in speech ? Surely not only by employing charged or "strong words" at random, or by combining complex polysemous words in enticing acts of speech, but also by framing these words in speeches structured to facilitate memorization. In 
other words (and in Sidney's phrase) the purpose was to enrich the judgment of one's hearers or readers. The tools and terminology of social and ideological plotting were rhetorical and first tested in the laboratory of humanist discourse be it in religious, legal, historical, economic, geographic, epic, or dramatic writing.

At the core of the humanist movement as it arose in Italy and developed in early and mid-sixteenth century England is the realization of man's crucial place between the bestial and the angelic and the inherent belief in the possibility to perfect a creature of such promise and potential. ${ }^{9}$ The position invited improvement through education and the renewed emphasis on virtuous action rather than contemplation. The lessons of Italian humanist teaching in treatises like Pico's De dignitate hominis and Valla's De voluptate legitimized the quest for knowledge and (to quote Arthur F. Kinney) was "the root cause of the humanists' exuberance and optimism." 10 In England it gave rise to a prolific production of books of instruction by men like Richard Mulcaster who set out "to examine the naturall abilities, which are to be perfited, \& how natur hirself doth forward the perfectio[n]." 11 We find the more extreme versions of this quest in Marlowe's overreaching protagonists. More generally the attitude opened the field to inventive projects of self-fashioning, ${ }^{12}$ so that "the emphasis on utility and practical application of theoretically elaborated grammars of action came to dominate all sectors of social life in the period."13

What was appreciated by the authorities and urged by humanist educators, however, was the ability to present persuasive discursive strategies which readers could convert into profitable projects in service of the commonwealth and/or could adapt to further their own private interests in what could be termed the patronage racket. The nation's intellectual life was channelled in one direction : all activities should make the commonwealth prosper at the same time as the individual was engaged in projects of self-representation. ${ }^{14}$ In this climate of building the nation and the man, architecture gradually assumed a greater symbolic value, a development clearly visible in Italian quattrocento theorists. ${ }^{15}$ In England this trend is seen in the emphasis on plotting, cogently described by Lorna Hutson, ${ }^{16}$ including a new interest in architecture. ${ }^{17}$

The idea of plotting involved conveys a set of different implications in Elizabethan literature than in modern fiction. To plot is a way of influencing and communicating effectively in fictional narrative or dramatic dialogue as much as in discourses on history, politics, warfare, and commerce. That this is so is seen in Sidney's acceptance of narrative fiction "as an imaginative ground plot for profitable invention," 18 a concern which is closely related to Italian humanists' discussions of the "architectonic end" of plot in tragedy. ${ }^{19}$ Gascoigne who was praised for "the golden ground / Of [his] plat" 20 constitutes no exception in this respect, but in his novella the private aspects plotting are dominant. For not only does the novella present discursive strategies relating to the conquest of a woman, ${ }^{21}$ it also becomes a site where Gascoigne can demonstrate his verbal ingenuity, thus proving his suitability for public office. One particular meaning of "plot" which is important to this demonstration of rhetorical skill surfaces in Gascoigne's reference to a poem's "platforme of invention" in Certain notes of instruction. ${ }^{22}$ Plot in this sense clearly 


\section{ARS COMBINATORIA}

indicates that the edifying or "architectonic end" of poetry depended not only on ideas but on their actual spatial arrangement and interrelationship within the text.

In fact, a poem was thought of as a spatial artifact having a "platforme" or "groundplot" on a par with a building. Thus the plot of a narrative like Gascoigne's Aduentures of Master F.J. or a play like Tamburlaine the Great would be conceived of as an area of land for building, or the ground plan of a building, or - in the traditional sense - as the outline of the action in narrative or drama. ${ }^{23}$ The particular aesthetic ideal involved has been aptly summarized by Per Palme in an article on Ben Jonson as the aesthetic of ut architectura poesis. ${ }^{24}$ The successful execution of "the platforme of invention" was the test of the poet's skill and its detection that of the reader. Would Marlowe's rhetoric fit into such a rhetoric of profitable plotting, or does he "overreach" all such constructive schemes ? When choosing several chronicles about the life of the Asian ruler Timur Lenk for his basic raw material, ${ }^{25}$ Marlowe follows closely the instructions of Sidney when he recommends narratives about the ancient prince Cyrus, for such narratives "bestow a Cyrus upon the world to make many Cyruses", and may teach readers to "learn aright why and how that maker made him." 26 Tamburlaine like Cyrus provides examples of virtue in action and the text displays discursive practices designed to educate the spectator and enable their judgment. This intention is also signalled by Richard Jones, the printer of Tamburlaine, in the play's "Preface to the Gentlemen Readers : and others that take pleasure in reading Histories." When Jones offers Marlowe's "honorable and stately [...] history," he stresses "the eloquence of the author" in addition to "the worthiness of the matter itself." The edifying aspects are also taken care of when he insists that he has "omitted and left out some fond and frivolous gestures, digressing and [...] far unmeet for the matter."27

When turning to the play itself upon this early example of advertising, we find that Marlowe applies rhetorical copia of matter and elocution by introducing examples of what the period considered useful readings. I here refer to geographical knowledge by the startlingly exact use of Ortelius's atlas, the Theatrum Orbis Terrarum (Antverp, 1570), ${ }^{28}$ and other contemporary authorities, while capitalising on the contemporary demand for travel books. Treatises on fortification are evoked, we find formal experiments drawn from Petrarch's In morte di madonna Laura in connexion with Tamburlaine's "impassionate fury for the death of his lady and love fair Zenocrate." Similarly advertised is "his form of exhortation and discipline to his three sons" in the vein of popular conduct books. To end a long list, there is a test of virtue and a variant of the topos of the questione d'amore in the Olympiaepisode, which again is lifted from Ariosto's Orlando furioso XXVIII-XXIX. These and other examples present knowledge about the world and suggest discursive strategies offered for imitation and re-use by contemporary and later authors.

Still the problem of the representation of power remains, albeit an obvious element in the presentation resides in the suggestive, often enticing, offer of pleasure : beauty, wealth, physical dominance. Marlowe deftly manipulates his audience by promises of pleasure, playing on their desires to dominate their fellow men and women. He takes the spectator by the hand in a manner similar to Tamburlaine's, who offers Theridamas friendship and rich rewards : 
Theridamas, my friend, take here my hand, Which is as much as if I swore by heaven And call'd the gods to witness of my vow.

Thus shall my heart be still combin'd with thine,

Until our bodies turn to elements,

And both our souls aspire celestial thrones.

Techelles and Casane, welcome him.

(Part One, I.2.232-8)

This manipulation functions on more levels than that of stage spectacle and fraught words. It also includes the plotting of series of events and speeches, and even the placing of significant words within single speeches. We are dealing with dispositio not only on the level of plot, but of speech : non solum fabula, sed etiam oratione.

In the speech which includes the well-known line, "Nature that framed us of four elements," we observe the application of such manipulative manœuvres in a piece of dramatic writing which openly treats different aspects of architecture or architektonike. Tamburlaine not only dreams about absolute power and knowledge, he also models himself on Jove in his quest :

The thirst of reign and sweetness of a crown,

That caus'd the eldest son of heavenly Ops,

To thrust his doting father from his chair

And place himself in the imperial heaven,

Mov'd me to manage arms against thy state.

What better precedent than mighty Jove?

Nature, that fram'd us of four elements

Warring within our breasts for regiment,

Doth teach us all to have aspiring minds.

Our souls, whose faculties can comprehend

The wondrous architecture of the world,

And measure every wandering planet's course,

Still climbing after knowledge infinite,

And always moving as the restless spheres,

Wills us to wear ouselves and never rest

Until we reach the ripest fruit of all,

That perfect bliss and sole felicity,

The sweet fruition of an earthly crown.

The speech proclaims the individuality of Renaissance man and his capacity to rise to power, in a rhetorical shape which bespeaks its relationship to the new rhetoric 


\section{ARS COMBINATORIA}

Alberti had devised for painting in De pictura. A dramatic speech is not a painting, but a speech does have a historia or narratio and is addressed to a viewer-listener who both perceives and watches what is being said. The situation where a viewer is watching a painting is not unrelated to the one where a spectator is watching an actor deliver a speech. Heninger writes as follows about the first of the two :

While the mathematical exactness of single-point perspective endows the painting with organic unity and sets it apart as a selfconsistent entity, orthogonal lines of the perspectival construct reach out of the painting and incorporate the space inhabited by viewers, thereby situating them in precise relationship to the objects within the frame. The space inhabited by the viewers is rendered continuous with that occupied by the painted objects. 29

A similar continuity exists in the theatre between actor and spectator, although some of the crucial signs used to frame the dramatic discourse are perceived only sub-liminally. If we disregard the optic and accoustic aspects of delivery to examine the patterned representation of the speech on printed paper, a speech like the one quoted has been "framed" in a manner related to how paintings are composed orthogonally. Thus Marlowe's will to frame - to build or construct a space for projection - Tamburlaine's ambition is evident in the way elements found in the opening line of verse "The thirst of reign and sweetness of a crown"crop again in the concluding line : "The sweet fruition of an earthly crown." In Mannerist poetic terminology, ${ }^{30}$ Marlowe can be said to "chain" the attention of the audience by repeating the suggestive words sweet / sweetness and crown in the marginal verses. Within the speech itself key-terms and topoi are repeated symmetrically so that the essential verb "moved" balances "moving" and the description of man as a "frame" of warring elements balances the syncretist notion of the world as architecture. At the centre of the 29-line speech "the aspiring minds" balance the "souls" which are still "climbing". Marlowe here aligns "movements within the microcosm and the macrocosm" in a speech of extraordinary vitality, where each step still is firmly controlled and measured. Yet, this control does not imply that the speech is static or characterised by "dead" symmetry, because its periods run on across verse units, leaving us almost breathless in its dynamic progress. The embedded pattern of repetitions can be represented graphically as follows :

sweetness

crown

mov'd

topos of man as "frame"

aspiring minds

souls (climbing)

topos of world as "architecture"

moving

sweet

crown 
The speech is an example of the Aristotelian formula for wholeness - it has a welldefined beginning, middle, and end, or displays a unity by verbal contrivance or elocution. Despite the dialectic and progressive linearity which naturally inheres in dramatic dialogue, the separate elements of its processual flow, the individual speech, and often also the totality of speeches in a scene or act, behave like one orthogonally well-disposed construct. ${ }^{31}$ In other words, a speech like the present behaves like a stanza, one of the "rooms" of poetry and therefore can be analysed spatially. Rhetorical questions like "What better precedent than mighty Jove" establish a strong emotional link between speaker and listener/viewer, inviting her or him into his room or frame of words.

This ideal of holism created from the combination of multiple parts is highlighted to a poetic ideal in the previously quoted speech from Tamburlaine Part Two, where it is expressed in the phrase "all the flowers of poesy", which when combined constitute "one poem's period" (V.2.107). As all students of Renaissance elocution know, a repetition is precisely a flower of poesy, so this description aptly designates the pattern of verbal repetitions in the speech I have discussed. The process is also briefly alluded to in Olympia's lines of distress :

No such discourse is pleasant in my ears,

But that where every period ends with death,

And every line begins with death again.

(IV.3.47)

To return to our speech, the printed page presents a built-in verbal pattern which seems to live a life of its own separate from the aggressively and suggestively floating periods of the speech. This is a pattern which the spectactors would have perceived only subliminally, one which would have enabled them to process the speech more easily as a framed whole in the best tradition of periodic rhetoric. We recall that the rhetorician Demetrius could compare the combination of words in a sentence to "the stones which support and hold together a vaulted dome." 32

On two earlier occasions I have discussed the proximity of Tamburlaine's phrases and imagery to the surging rhetoric of De gli eroici furori (1585), Giordano Bruno's moral dialogues. Since the very name of the philosopher still seems to cause anxiety among critics unfamiliar with his intellectual formation or mannerist poetic style, it may be reassuring to know that behind the sentiments expressed by Marlowe's persona a number of venerable names may be marshalled, writers like Ovid, Philo Judaeus, Augustine, and Calvin. That the quest for knowledge involved in Tamburlaine's speech was acceptable to many Elizabethan intellectuals, we see most strikingly perhaps in the opening stanza of Fulke Greville's A Treatise of Humane Knowledge :

The Mind of Man is this worlds true dimension;

And Knowledge is the measure of the mind:

And as the minde, in her vast comprehension, 


\section{ARS COMBINATORIA}

Containes more worlds than all the world can finde:

So Knowledge doth itselfe farre more extend,

Than all the minds of Men can comprehend. 33

This reads like a sober version of man's quest for knowledge infinite in Tamburlaine, and it is tempting to see Marlowe's speech as a poetic reworking of Greville's synthetic argument, somewhat in the vein of the dramatist's response to Spenserian poetry in the same play, as argued by David Cheney.34 Tamburlaine's speech focuses on the same key-words (knowledge, world, mind, comprehend) as those used by Greville, and is framed rhetorically in a similar way. The stanza, too, contains an embedded holistic pattern - a frame or platform - of the kind uncovered in Tamburlaine's speech. We again should keep in mind that a stanza is a textual unit which also could be conceived as a room in an architectural sense, as taught by Torquato Tasso or Samuel Daniel. As such it should be "a iust period",35 that is, it is endowed with the formal properties that produce one poem's period. Indeed, Greville's stanza possesses a plot or platform signalled by the internal distribution of its elements according to what Puttenham would have termed "proportions poeticall". If we write out the principal repetitions separately we get the following verbal configuration :

$\begin{array}{ll}\text { The Mind of Man } & \text { worlds } \\ \text { Knowledge } & \begin{array}{l}\text { mind } \\ \text { comprehension } \\ \text { mind }\end{array} \\ \text { worlds } & \text { the world } \\ \text { Knowledge } & \text { comprehend } \\ \text { the minds of Men } & \end{array}$

These repetitions may not all be completely symmetrical, but they fall into place once the inherent system of organisation has been perceived, that is, a system which privileges the beginning, the middle, and the end. First the beginning is connected with the end, when the words "the Mind of Man" and "Knowledge" in lines 1-2 are inverted in verses five and six, forming a macrochiasmus (abba) englobing the entire stanza. Then we note that the stanza's middle position (and the word "comprehension" in verse three) is linked to the end (via the word "comprehend" in verse six), the rhetorical figure used being epanados. The remaining recurrences (world[s] and mind) are also fairly evenly distributed within the body of the stanza, testifying to Greville's will to shape his important opening argument. To use a phrase by Marlowe from an equally well-plotted piece of writing, he has produced "a sure and grounded argument". ${ }^{36}$

Such framed texts give evidence of the close connection between ethics, aesthetic and architecture in humanist thought. When a writer is engaged in producing a profitable discourse, he is also engaged in a spiritual and/or moral aedificatio. To illustrate this technique, let us return to the early days of humanism and Leon Battista Alberti. A celebrated passage in his Profugiorum ab aerumna, ${ }^{37}$ the archi- 
tect-scholar's description of the cupola of Santa Maria del Fiore, sheds light upon the close connection between ethics and architecture in his writings on art. The moral dialogue is a work in three books about how to shield the mind against distress. One of the interlocutors, Agnolo, tells us about various intellectual exercises he has devised in order to sooth his agitated mind [mie agitazioni d'animo] and fortify it against external disturbance, one of which involves the imagined construction of a classically inspired edifice :

E talora [...], composi a mente e coedificai qualche compositissimo edificio, e disposivi più ordini e numeri di colonne con vari capitelli e base inusitate, e collega'vi conveniente e nuova grazia di cornici e tavolati. (III.182)

"And at one time [...] I composed in mind and put together some well-assembled edifice, and there arranged various Orders and numbers of columns with diverse capitals and unusual bases, and I added to it a convenient and novel grace by way of cornices and marble plaques."

The mind is trained to create a bulwark against adversity via what appears to be an architectural fantasy. Judging by the details, that fictional architectural construct is characterized both by concinnitas and varietas. Symmetry is here suggested by terms like "coedificai qualche compositissimo edificio" and "conveniente [...] grazia", which bring to mind the Latin term convenientia both in a Ciceronian and an Augustinian sense, whereas variety is equally prominent in terms like "vari capitelli e basi inusitate" and "nuova grazia".

Such abstract investigations which also could involve the composition and re-composition of poetry and fiction, ${ }^{38}$ occupy an important place in Alberti's vaster project of utilitas. In fact, the investigations are most valuable when they can be developed for practical use in human life ("qualche utile pratica in vita"), that is, what the Elizabethans later would term profitable discourse. Christine Smith has recently explained the mental preparation here outlined by Alberti as the creation of "another nature within ourselves," arguing that "[s]piritual tranquillity [...] is a human creation, built up as a moral edifice through human intention, knowledge, and skill." 39 Alberti appears not to have used the term altra natura explicitly, but behind this kind of reasoning, which became current in the century to follow, ${ }^{40}$ we discern the ancient description of how man modified the environment to his own benefit, using nature as a model..$^{41}$ Cicero, who is everywhere present in Alberti's thinking, had outlined that process in De natura deorum. ${ }^{42}$ To Cicero "[n]ature is our teacher and guide," 43 and he numbers architecture among the useful arts in which man exerts his capacity to create another nature. ${ }^{44}$ This combination of ethics and building, which is so essential to Cicero's influential treatise, was taken over and developed in De re aedificatoria, prompting its division into usus versus pulchritudo and ornamentum. ${ }^{45}$ Basing himself on Cicero, Alberti transfers this 
rapport from the private to the public sphere: "because we decorate our house as much to adorn our fatherland and family [patriae familiaeque condecorandae] as for the sake of elegance, who will deny that such activity is the duty of a good man [boni viri officium] ?" However, the division into opus and ornamentum does not posit an absolute opposition between the two aspects of the art, for Alberti works from "the premise that composition [opus] and refinement [ornamentum] are inseparable components of the art of building," 46 as indeed they are of the art of writing in the period, including that of Alberti. ${ }^{47}$ Adornment, that is, the application of rhetorical figures is acceptable when controlled by utility, and at this point Marlowe's use of humanist poetics becomes increasingly problematic.

Tamburlaine's appeal to the "[n]ature that fram'd us of four elements" repeats the Cicero-Albertian topos of "natura ipsa magistra et duce", while his entire speech gives us the recipe of how to create a second nature. But his goal is not to fortify the mind, to secure spiritual tranquillity, nor gather knowledge for the greater good of the body politic, he aims at personal conquest and world dominion. Marlowe therefore employs the humanists' technique of plotting speeches in a new and more individual-oriented direction that allows a greater degree of self-fashioning. That this kind of rhetorical plotting is mannerist in essence, we see in its unclassical dissociation of form and content, when several periods are combined and treated as one syntactic unit, a practice which was criticized by Scaliger in the Poetices libri septem (1567), where he scorned false periods in which repetitions in space replace syntactic cohesion. ${ }^{48}$ While Marlowe's practice would have annoyed classicists like Scaliger and Jonson, it would surely have pleased a mannerist like Vasari, who advocated "ordine con più ornamento" (order with more ornament), which also would be a suitable characterization of Marlowe's artful combination of words.

A number of the speeches in Marlowe's œuvre have been equipped with rhetorical patterns similar to Tamburlaine's speech. Some of these are elaborate and carefully patterned with exotic words which shine like gems to entice our minds, while others use simple and unimpressive repetitions :

(1) But now you see these letters and commands Are countermanded by a greater man And through my provinces you must expect Letters of conduct from my mightiness, If you intend to keep your treasure safe.

But, since I love to live at liberty, As easily you may get the Soldan's crown As any prizes out of my precinct : For they are friends that help to wean my state Till men and kingdoms help to strengthen it, And must maintain my life exempt from servitude.

But tell me, madam, is your grace betroth'd?

(Part One, I.2.21-32; my emphasis). 
(2) Come, my Meander, let us to this gear.

I tell you true, my heart is swoll'n with wrath

On this same thievish villain, Tamburlaine, And of that false Cosroe, my traiterous brother.

Would it not grieve a king to be so abus'd And have a thousand horsemen ta'en away?

And, which is worst, to have his diadem Sought for by such scald knaves as love him not?

I think it would. Well then, by heavens I swear, Aurora shall not peep out of her doors But I will have Cosroe by the head And kill proud Tamburlaine with point of sword. Tell you the rest, Meander; I have said.

(Part One, II. 2. 1-13; my emphasis)

(3) And ride in triumph through Persepolis!

Is it not brave to be a king, Techelles, Usumcasane, and Theridamas?

Is it not passing brave to be a king, And ride in triumph through Persepolis?

(Part One, II.5. 50-4; my emphasis)

(4) Oh, good my lord, be patient. She is dead, And all this raging cannot make here live. If words might serve, our voice hath rent the air; If tears, our eyes have watered all the earth; If grief, our murdered hearts have strain'd forth blood, Nothing prevails, for she is dead, my lord.

(Part Two, II.4.119-24; my emphasis)

These four examples do not include any of the really extended and highly patterned speeches in the two plays, but they may be considered as fairly representative of the kinds of structured repetitions found in Marlowe's dramatic speeches. Examples 2 and 3 are typical of the deployment of names, often exotic and strange names, used as structural markers, a technique we encounter in several of the speeches on Zenocrate (Part One, I.2.82-105 and Part Two, II.4.1-38). Example one shows a speech structured by the symmetrical repetition of the simple word "but" plus the repetition of words between the speech's middle and its ending verses (epanados). The fourth example is a typical example of pathos where strongly loaded words here "she is dead" is repeated together with a term of address ("my lord"). In fact, 


\section{ARS COMBINATORIA}

$31.14 \%$ of the text of Part One is found in such structured segments, 59 segments in all. In Part Two $24.67 \%$ of the text is found in such segments and their number is 42, figures showing Marlowe's widespread use of this kind of verbal plotting. ${ }^{49}$

When we realise that a substantial portion of Marlowe's speeches have been constructed in this manner, which moreover Shakespeare more than any other dramatist readily adopted, one would expect this to have repercussions on how we consider the style and the structure of Renaissance plays. The relationship between the two versions of Marlowe's Doctor Faustus is another case in point, where the stylistic characteristics of the central scenes in the B-text are such as to rule out the authorship of Samuel Rowley once and for all and firmly place the version in the early $1590 \mathrm{~s} .{ }^{50}$ To many students of Renaissance lyric and epic such formal findings will come as no surprise, as we find these rules of composition exemplified in the period's leading poets, notably in Gascoigne, Spenser, Daniel and Chapman and described and practiced in detail by Italian theorists and writers such as Ariosto, Della Casa, and Tasso. It should come as no surprise to students of Renaissance drama that Elizabethan dramatists, too, actually composed or plotted playtexts according to the rules taught in schools and rhetorical manuals, although recent editors of Marlowe's plays have failed to make such evidence bear on editorial practice. ${ }^{51}$ The mature Ben Jonson reminds us of this in a well-known passage which uses the humanists' favourite architectural metaphor :

in the constitution of a poem, the action is aimed at by the poet, which answers place in a building, and that action hath his largeness, compass, and proportion. So the epic asks a magnitude, from other poems: since, what is place in the one is action in the other, the difference is in space. 52

This, too, is precisely how Marlowe plots his dramatic texts in a spatial and architectural sense to achieve the maximum impact. He adjusts and revises the humanist mode of composition, appealing directly to the appetites of the audience in his presentation of a world of profit and omnipotence. Thus he elicits a positive response from the audience to dreams which they strictly speaking should repudiate and criticise, unless they should want to become new Tamburlaines. Although essentially a technique of edification drawing on the idea of a divine and ethically sound "wondrous architecture", Marlowe's practice of humanist poetics, his ars combinatoria, therefore shows rhetoric to be an efficient, but slippery, means of manipulating audience response.

Roy ERIKSEN Université de Troms $\varnothing$ 
1 See "Marlowe's Fascinations" in N. Rhodes, The Power of Eloquence and English Renaissance Literature, New York, St Martin's Press, 1992, pp. 69-117. References to Tamburlaine are from J.D. Jump ed., London, Edward Arnold, 1967.

2 Lorna Hutson, Thomas Nashe in Context, Oxford U. P., 1989, p.63.

3 See Sir Thomas Smith, A Discourse of the Commonweal of this Realm of England, 1581, ed. Mary Dewar (Charlottesville, U. of Virginia Press, 1969), and on a more trivial level, works like William Fulwood's Enemie of Idlenesse (1568).

G. Puttenham, The Arte of English Poesy, 1587, rpd. Cambridge U. P., 1936.

Proportion Poetical University Park Pen State U. P., 1994 "Alberti' Window

The Rhetoric of Perspective," pp. 155-95, esp. p. 170.

6 Sir Philip Sidney, An Apology for Poetry, ed. Geoffrey Shepherd, Manchester U. P., 1965, (rpd 1980), pp. 104: 28-35.

7 Cf. Rudolf Wittkower, Architectural Principles in the Age of Humanism, 1949; London, Thames and Hudson, 1991, and the application of architectural design to the shape of the sonnet in S. K. Heninger Jr., The Subtext, pp. 69-118.

8 See my discussion of these in 'The Forme of Faustus Fortunes' : A Study of Dr. Faustus (1616), Oslo and Atlantic Highlands, N.J., Solum and Humanities Press, 1987, p. 16 and in "Marlowe's Petrarch; In Morte di Madonna Laura", Cahiers Elisabéthains, 26, 1986, 13-25.

9 See P.O. Kristeller's account of this position in Renaissance Thought and Its Sources, ed. Michael Mooney, New York, Harper and Row, 1979, pp. 174-75.

10 See Arthur F. Kinney, Humanist Poetics: Thought, Rhetoric, and Fiction in Sxteenth-Century England, Amherst, U. of Massachusetts Press, 1986, p. 6.

11 Quoted by Kinney, Humanist Poetics, p. 6.

12 S. Greenblatt, Renaissance Self-Fashioning From More to Shakespeare, Chicago U. P., 1979, "Marlowe and the Will to Absolute Play," pp. 193-221. 


\section{ARS COMBINATORIA}

13 Cf. R. Eriksen, "The Lineaments of Influence : Alberti and the Elizabethans," in Gunnar Sorelius and Michael Srigley eds., Cultural Exchange between European Nations during the Renaissance (Uppsala, Almquist and Wiksell, 1994), pp. 69-84.

14

See Richard Helgerson's Forms of Nationhood, Chicago U. P., 1992.

15

J. Onians, Bearers of Meaning. The Classical Orders in Antiquity, the Middle Ages, and the Renaissance, Princeton U. P., 1988; Christine Smith, Architecture in the Culture of Early Humanism: Ethics, Aesthetics, and Eloquence 1400-1470, Oxford U. P., 1992, pp. 3-19.

16 See Hutson's book, and the article "Fortunate Travelers : Reading for the Plot in the English Renaissance," Representations 41 (Winter, 1993), pp. 83-103.

17

"The Lineaments of Influence: Alberti and the Elizabethans," p. 83.

18

An Apology for Poetry, p. 124: 26-27.

19

B. Weinberg, A History of Literary Criticism in the Italian Renaissance, Chicago U. P., 1961, pp. 28, 516, 544.

20 The Works of George Gascoigne, ed. J. W. Cunliffe, Cambridge U. P., I: 27.

21 This would appeal to young gentlemen at the Inns of Court, whom Gascoigne singles out in the prefatory material to The Posies, and who were eager to find surviving copies of the 1573-edition of his novella; cf. "The Mimesis of Change : Gascoigne's Aduentures of Master F.J.," in ed. R. Eriksen, Contexts of Pre-novel Narrative : The European Tradition, Mouton de Gruyter, 1994, pp. 185228.

22 The Complete Works, I: 469.

23 See P. Brooks, Reading for the plot: Design and Intention in Narrative, New York, Vintage Books, 1985, pp. 11-12 and Hutson, "Fortunate Travelers," pp. 84ff.

24 "Ut Architectura Poesis," in Idea and Form, ed. Nils G. Sandblad,Uppsala, Almquist and Wiksell, 1959, pp. 95-107.

25 The two main sources appear to be Perondinus, Magni Tamerlanis Scytharum Imperatoris Vita, Florence, 1553, and G. Whetstone, The English 
Myrror, London, 1586. See U. M. Ellis-Fermor ed., Tamburlaine the Great, London, 1930, pp. 17-52.

26 An Apology for Poetry, p. 101: 10-14.

27 The epistle is printed in ed. Jump, pp. 3-4.

28 E. Seaton, "Marlowe's Map," Essays and Studies by Members of the English Association, X (1924), pp. 13-35.

29 S. K. Heninger, The Subtext, p. 167.

30 G. Bruno, De vinculis in genere, Pordenone,, 1986, p. 188.

31 Mark Rose, Shakespearean Design, Cambridge, Mass.; Harvard U. P., 1972).

32 Demetrius, On Style, trans. W. Rhys Roberts, Harvard U. P. and Heinemann, 1923, rpd 1982, I:13.

33 Quoted from Kinney, Humanist Poetics, p. 3.

34 See David Cheney's stimulating revision of the relationship between Spenser and Marlowe at the Corpus Christi Conference.

35 Samuel Daniel, A Defence of Ryme, London, 1603, p. 16.

36 Part One, I.2.165-209.

37 Profugiorum ab aerumna, in ed. Cecil Grayson, Opere volgari, Bari, Laterza, 1966, pp. 105-183. The work which has not received much attention in scholarship is discussed in context by Christine Smith, Architecture.

38 Cf. Alberti : "I often occupy myself with learning a poem or an excellent piece of prose by heart, beginning to comment upon it and add ornaments to it, while amplifying its argument", Profugiorum, III. 181 (my translation).

Architecture, p. 7.

40

Apology for Poetry, p. 100: 23. 
41 See Claudia Lazzaro, The Italian Renaissance Garden. From the Conventions of Planting, Design, and Ornament to the Grand Gardens of SixteenthCentury Central Italy, New Haven, Yale U. P., who cites several cinquecento examples, p. 9. She mentions the garden as a third nature that grew out of established notions of art and nature, and recalled a related concept of a second nature.

42

Cicero explains the process in De natura deorum : "We sow corn and plant trees. We fertilize the soil by irrigation. We dam the rivers, to guide them where we will. One may say that we seek with our human hands to create a second nature in the natural world", trans. H. C. P. McGregor, Penguin, 1973, 2.152, p. 185.

43 De Officiis, I.xxxv.129: "[N]atura ipsa magistra et duce" (p. 130), and also "[n]os autem naturam sequamur" (p. 130).

Cf. Cicero, De natura deorum, II.lx.150.

45 J. Onians, "Alberti and Filareth," Journal of the Courtauld and Warburg Institute, XXXIV (1971): 97-114, p. 103.

46 Richard Tobin, Leon Battista Alberti : Ancient Sources and Structure in the Treatises of Art (Phd. Bryn Mawr College, 1979), p. 149.

47 See my analysis of Alberti's prose in "The Lineaments of Influence, " p. 714.

48 Poetices libri septem (1561), Stuttgard-Bad Cannstatt, 1964, III. 197.c.2.

49 For a full survey, see 'The Forme of Faustus Fortunes' (1616), p. 217.

50 The Forme of Faustus Fortunes, pp. 193ff.

51 D. Bevington and E.Rasmussen have a brief section on "Style and imagery" in their otherwise full edition, but choose to rehearse old misconceptions concerning Rowley's style rather than to engage with evidence of Marlowe's compositional style. Cf. Marlowe's Doctor Faustus (1604, 1616), Manchester U. P., 1993, p. 72.

52 Ben Jonson, Timber : or Discoveries, Syracuse, N.Y., Syracuse U. P., 1976, p. 43. 